\title{
Cerebral haemorrhagic infarction associated with acute otitis media in a 4-year-old boy
}

\author{
Yuji Fujita (1), ${ }^{1}$ George Imataka, ${ }^{1}$ Misako Ohkusu, ${ }^{2}$ Shigemi Yoshihara ${ }^{1}$
}

${ }^{1}$ Department of Pediatrics, Dokkyo Medical University, Shimotsuga, Tochigi, Japan ${ }^{2}$ Department of Infectious Diseases, Medical Mycology Research Center, Chiba University, Chiba, Japan

\section{Correspondence to}

Dr Yuji Fujita;

fujitay@dokkyomed.ac.jp

Accepted 5 May 2021

\section{DESCRIPTION}

A 4-year-old boy had cough and purulent nasal discharge 2 days before admission; he also had fever, headache, vomiting and left ear pain. $\mathrm{He}$ received amoxicillin $(40 \mathrm{mg} / \mathrm{kg} /$ day $)$ and was diagnosed with left acute suppurative otitis media (AOM) by an otorhinolaryngologist, the same day. The next day, he developed right clonus of the upper and lower limbs and was administered midazolam. He was immediately referred to our hospital; he was sedated at the time of admission due to midazolam. Physical examination revealed redness on the left eardrum and pus in the left ear canal, without a heart murmur, stiff neck or Kernig's sign. Blood examination showed a white cell count of $12.2 \times 10^{9} / \mathrm{L}$ cells $/ \mu \mathrm{L}$, C-reactive protein level of $16.54 \mathrm{mg} / \mathrm{dL}$, procalcitonin level of $0.32 \mathrm{pg} / \mathrm{mL}$, prothrombin time international normalised ratio of 1.11 , activated partial thromboplastin time of $32.3 \mathrm{~s}$, fibrinogen level of $524 \mathrm{mg} /$ $\mathrm{dL}$ and D-dimer level of $0.6 \mu \mathrm{g} / \mathrm{mL}$. Cerebrospinal fluid (CSF) examination showed a CSF pressure of $50 \mathrm{~mm} \mathrm{Hg}$, a cell count of 21 cells $/ \mu \mathrm{L}$, glucose level of $99 \mathrm{mg} / \mathrm{dL}$ (CSF/serum glucose ratio of 0.77 ) and protein level of $29.7 \mathrm{mg} / \mathrm{dL}$. Brain diffusionweighted and T2-star-weighted MRI showed two lesions of haemorrhagic infarctions in the left hemisphere (figure 1A-C). Brain T2-weighted MRI showed a high signal in the mastoid part and tympanic cavity (figure 1D). Brain magnetic resonance angiography (MRA) showed no abnormal findings in the cerebral artery. Head CT showed no anatomical abnormalities indicating direct central nervous system spread, including bone destruction. Echocardiography showed no signs of underlying cardiogenic-embolism-causing diseases, including infectious endocarditis. He was administered cefotaxime, ampicillin and corticosteroid. Blood and cerebrospinal cultures at admission were negative. Haemophilus influenzae was detected via CSF PCR. Transient aphasia, right facial nerve paralysis and right hemiplegia were observed. Although he had difficulty moving his right hand, he was discharged independently.

AOM can occasionally cause cerebral complications, including bacterial meningitis, brain abscesses and lateral sinus thrombosis. ${ }^{1}$ Haemorrhagic infarction caused by AOM is extremely rare. Massive ischaemic stroke after cerebral artery infarction caused by AOM has been reported. ${ }^{2}$ In the case, haemorrhagic infarctions were not considered arterial infarctions because MRA showed no abnormal findings and haemorrhagic infarctions were observed in different areas of the artery. Therefore, haemorrhagic

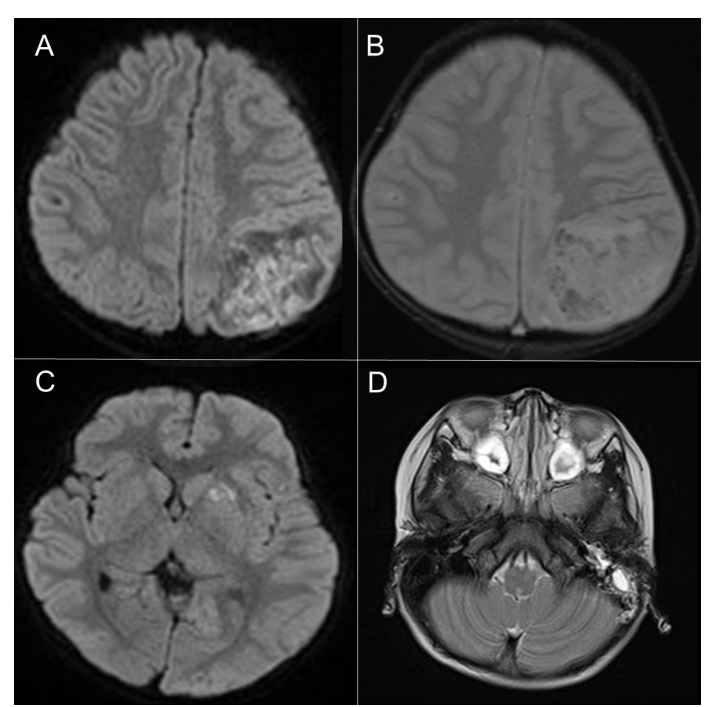

Figure 1 (A) Brain diffusion-weighted ( $b=1000 \mathrm{~s} /$ $\mathrm{mm}^{2}$ ) MRI showing reduced diffusivity, manifested as high intensity in the left parietal lobe. (B) Brain T2star-weighted MRI showing low intensity around the periphery of the infarction. (C) Brain diffusion-weighted MRI showing small infarction in the left basal ganglia. (D) T2-weighted MRI showing high signal in the left mastoid part, left tympanic cavity and bilateral paranasal cavities.

infarctions were believed to be caused by venous infarctions. Cerebral venous infarction due to AOM is extremely rare, ${ }^{3}$ and a massive haemorrhagic infarction, as in our case, has not been reported.

In our case, $H$. influenzae was detected via CSF by PCR; however, we believe that the haemorrhagic infarction in our case was not caused by bacterial meningitis because it was observed on the side

\section{Patient's perspective}

We are glad that our son's life was saved, although he had some neurological sequelae.

\section{Learning points}

Causative organism can be identified by PCR of cerebrospinal fluid even with prior administration of antibiotics.

- Acute otitis media rarely causes cerebrospinal complications such as haemorrhagic infarction.

- It is important to empirically administer antibiotics in cases of haemorrhagic infarction. 
with otitis media, and the cell count in the CSF was inadequate for bacterial meningitis. It was speculated that the infarction was caused by the embolism of haematogenously spreading bacteria; the secondary bleeding after the infarction might have caused the leakage of bacteria into the CSF.

Paediatricians should remember that AOM rarely causes cerebrospinal complications.

Acknowledgements We would like to thank Editage (www.editage.com) for English language editing. We would like to thank Dr Shigeko Kuwashima, Department of Radiology, Dokkyo Medical University and Professor Jun-ichi Takanashi, Department of Paediatrics, Tokyo Women's Medical University Yachiyo Medical for advising us regarding the diagnosis in our case.

Contributors Dr YF collected and analysed the data, drafted and revised the initial manuscript. Dr GI, Dr MO and Professor SY interpreted all the data and critically revised the manuscript for important intellectual content. All the authors read and approved the final manuscript.
Funding The authors have not declared a specific grant for this research from any funding agency in the public, commercial or not-for-profit sectors.

Disclaimer Case reports provide a valuable learning resource for the scientific community and can indicate areas of interest for future research. They should not be used in isolation to guide treatment choices or public health policy.

Competing interests None declared.

Patient consent for publication Parental/guardian consent obtained.

Provenance and peer review Not commissioned; externally peer reviewed.

\section{ORCID iD}

Yuji Fujita http://orcid.org/0000-0001-6440-9110

\section{REFERENCES}

1 Penido NdeO, Borin A, tha LCN, et al. Intracranial complications of otitis media: 15 years of experience in 33 patients. Otolaryngol Head Neck Surg 2005;132:37-42.

2 Pasha HM, Mirsky DM, Streubel SO. Massive ischemic stroke as a complication of otitis media. Int J Pediatr Otorhinolaryngol 2015;79:1771-3.

3 Özer E, Sıvaslı E, Bayazıt YA, et al. Otogenic cerebral venous infarction: a rare complication of acute otitis media. Int J Pediatr Otorhinolaryngol 2003;67:1019-21.

Copyright 2021 BMJ Publishing Group. All rights reserved. For permission to reuse any of this content visit

https://www.bmj.com/company/products-services/rights-and-licensing/permissions/

BMJ Case Report Fellows may re-use this article for personal use and teaching without any further permission.

Become a Fellow of BMJ Case Reports today and you can:

- Submit as many cases as you like

- Enjoy fast sympathetic peer review and rapid publication of accepted articles

- Access all the published articles

- Re-use any of the published material for personal use and teaching without further permission

\section{Customer Service}

If you have any further queries about your subscription, please contact our customer services team on +44 (0) 2071111105 or via email at support@bmj.com.

Visit casereports.bmj.com for more articles like this and to become a Fellow 